
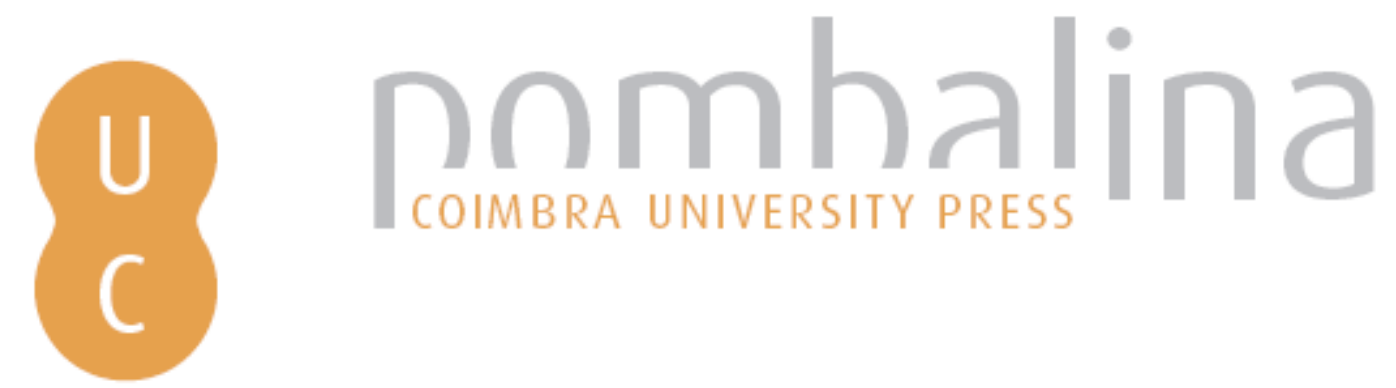

\title{
Mid-term effects of thinning on canopy variables related to crown fire hazard on pure, even-aged pine stands
}

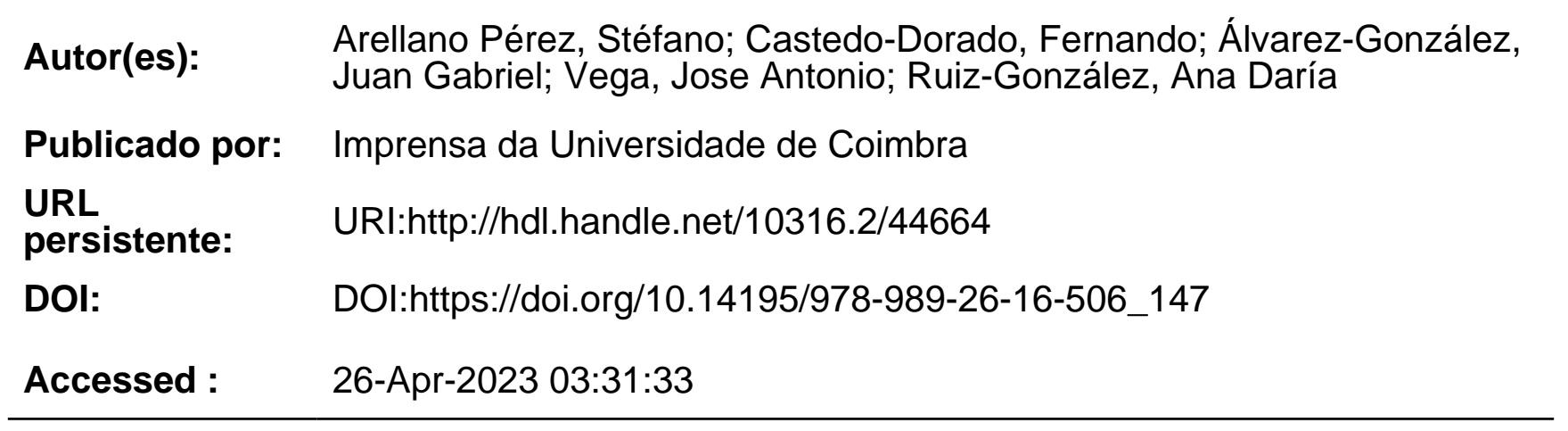

A navegação consulta e descarregamento dos títulos inseridos nas Bibliotecas Digitais UC Digitalis, UC Pombalina e UC Impactum, pressupõem a aceitação plena e sem reservas dos Termos e Condições de Uso destas Bibliotecas Digitais, disponíveis em https://digitalis.uc.pt/pt-pt/termos.

Conforme exposto nos referidos Termos e Condições de Uso, o descarregamento de títulos de acesso restrito requer uma licença válida de autorização devendo o utilizador aceder ao(s) documento(s) a partir de um endereço de IP da instituição detentora da supramencionada licença.

Ao utilizador é apenas permitido o descarregamento para uso pessoal, pelo que o emprego do(s) título(s) descarregado(s) para outro fim, designadamente comercial, carece de autorização do respetivo autor ou editor da obra.

Na medida em que todas as obras da UC Digitalis se encontram protegidas pelo Código do Direito de Autor e Direitos Conexos e demais legislação aplicável, toda a cópia, parcial ou total, deste documento, nos casos em que é legalmente admitida, deverá conter ou fazer-se acompanhar por este aviso.

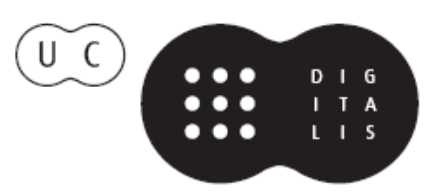




\section{ADVANCES IN}

\section{FOREST FIRE RESEARCH}

\section{8}

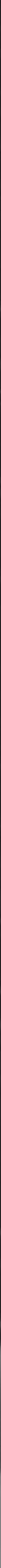


Short contribution - Fuel Management

\title{
Mid-term effects of thinning on canopy variables related to crown fire hazard on pure, even- aged pine stands
}

\author{
Stéfano Arellano Pérez ${ }^{1 *}$; Fernando Castedo-Dorado²; Juan Gabriel Álvarez-González¹; Jose Antonio \\ Vega $^{3}$; Ana Daría Ruiz-González ${ }^{1}$ \\ ${ }^{I}$ Department of Agricultural and Forestry Engineering. University of Santiago de Compostela. Campus \\ universitarios/n 27002,Lugo,Spain.\{stefano.arellano@usc.es*, juangabriel.alvarez@usc.es, \\ anadaria.ruiz@usc.es\} \\ ${ }^{2}$ Departamento de Ingeniería y Ciencias Agrarias, Universidad de León, Campus de Ponferrada, 24401, \\ Ponferrada, Spain. \{fcasd@unileon.es\} \\ ${ }^{3}$ Centro de Investigación Forestal de Lourizán, PO Box 127, 36080, Pontevedra, Spain. \\ \{joseantonio.vega.hidalgo@xunta.gal\}
}

\begin{abstract}
One of the main objectives of forest stand management in Mediterranean areas of Europe is the mitigation of crown fire hazard. Effective silvicultural strategies for reducing the likelihood and intensity of crown fires include reducing surface fuels, increasing canopy base height $(C B H)$ and reducing canopy bulk density $(C B D)$. All these fuel variables depend to a certain degree on stand structure and are therefore responsive to stand density management through thinning treatments. It is well known that canopy fuel load $(C F L)$ and $C B D$ diminish and $C B H$ increases immediately after thinning from below. Nevertheless, for how long the thinning effect be sustained and whether it could be species-specific is less clear. We examined how different levels of thinning intensity altered canopy fuel variables in the mid-term in Pinus pinaster and Pinus radiata stands. We used data from 41 thinning trial locations installed in pure, even-aged stands of $P$. pinaster (22 locations) and $P$. radiata (19 locations). At each location, three rectangular plots were established and a different treatment was applied to each plot: control (unthinned), low thinning (20\% of the basal area removed), and heavy thinning ( $40 \%$ of the basal area removed). Six years after treatments, $C B D$ and $C F L$ in treated plots were still significantly lower than in untreated plots for both species. Moreover, for radiata pine, $C B D$ values were even lower than in the pre-thinning situation. On the other hand, $C B H$ did not show any change following thinning in $P$. pinaster, whereas for $P$. radiata, heavy thinning resulted in significantly lower $C B H$ values since four years after the treatment. The results highlight that thinning may only have a limited impact towards diminising the potential for crown initation, especially in maritime pine stands, altough they could significantly influence the crown fire rate of spread in stands of both species.
\end{abstract}

Keywords: Canopy fuel load, Canopy Base Height, Canopy Bulk Density, Maritime pine, Radiata pine

\section{Introduction}

Mediterranean pine stands without proper fuel management are prone to high-intensity crown fires. Effective silvicultural strategies for reducing the likelihood and intensity of crown fires are aimed to decrease quantity and continuity of forest fuels. The initiation and spread of crown fires in pine stands are strongly influenced by three canopy fuel stand variables: canopy base height $(C B H)$, canopy fuel load $(C F L)$ and canopy bulk density $(C B D)$ (Van Wagner, 1977). These variables are responsive to stand density management, i.e., thinning treatments (Ruiz-González et al., 2015; Hevia et al., 2018). Although it is well known that both $C F L$ and $C B D$ diminish and $C B H$ increase immediately after thinning from below, for how long that effect will be sustained is less clear. The main objective of this work was to evaluate the mid-term effects of thinning on these variables in pine stands. 


\section{Material and Methods}

The study area was located in the North-west of Spain. The dataset corresponds to 41 thinning trial locations installed in pure, even-aged stands of Pinus pinaster (22 locations) and $P$. radiata (19locations). At each location, three rectangular plots $\left(1000 \mathrm{~m}^{2}\right.$ in size $)$ were established and a different treatment was applied to each plot: control (unthinned), low thinning (20\% of the basal area removed) and heavy thinning (40\% of the basal area removed). The plots were thinned from below immediately after plot establishment in 2009-10 and were re-measured in winter 2011-12, winter 201314 and winter 2015-16.

The values of $C B H, C F L$ and $C B D$ were estimated from tree diameter, height and height to the base of live crown measurements. The 'load over depth' method', proposed by Van Wagner (1977), was used to define these variables. According to this method, $C B H$ was calculated as the vertical distance between the ground surface and the mean crown base height; $C F L$ was calculated as the biomass of needles and fine twigs (up to $5 \mathrm{~mm}$ at the thick end) which were considered as the fuel that is assumed to be consumed within the flaming front of a crown fire; and $C B D$ was calculated by dividing $C F L$ by the canopy length, estimated as the difference between the mean stand height and $C B H$. Species-specific equations were used to estimate the biomass of needles and fine twigs (DiéguezAranda et al., 2009).

Analyses of variance (ANOVA) were conducted to assess the influence of the thinning intensity on the canopy variables of each inventory. Differences between mean values were evaluated with the Tukey's HSD test $(\alpha=5 \%)$. The value of the canopy variable analysed measured on the previous inventory was included in the ANOVA as a covariate for all post-treatment comparisons.

\section{Results}

Box-plots of each canopy fuel variable, differentiating by species, thinning intensity and inventory are shown in Figure 1. The results indicate that the values of the three canopy fuel variables on both species before thinning treatments (BT, 2009-10) were not significantly different between plots assigned with different thinning intensities.

Significant differences between thinning intensities were found for $C F L$ and $C B D$ for both species in the first post-thinning remeasurement (2011-12). Moreover, the differences were maintained along the 6-year period analyzed with a similar pattern for both species. The observed $C B D$ values in the thinning plots at the end of the study period (2015-16) reached the values before thinning for maritime pine but not for radiata pine. The response of $P$. pinaster $C B D$ and $C F L$ agreed with previous results (Jiménez et al., 2016) in a 5 years study, but contradicts the results of Soler et al. (2017) who did not find change in $C D B$ seven years after thinning. It must be noted that the latter study was carried out in older stands and under Mediterranean climate with less precipitation. Fuel management to reduce $C B D$ below the empirical threshold value of $0.10 \mathrm{~kg} / \mathrm{m}^{3}$ has been recommended since the likelihood of active crown fire is strongly reduced (e.g. Scott and Reinhardt, 2001). Six year after treatments only the mean value of the radiata pine trials with heavy thinning remains below this threshold (Figure 1, red dotted line for $C B D$ ). 

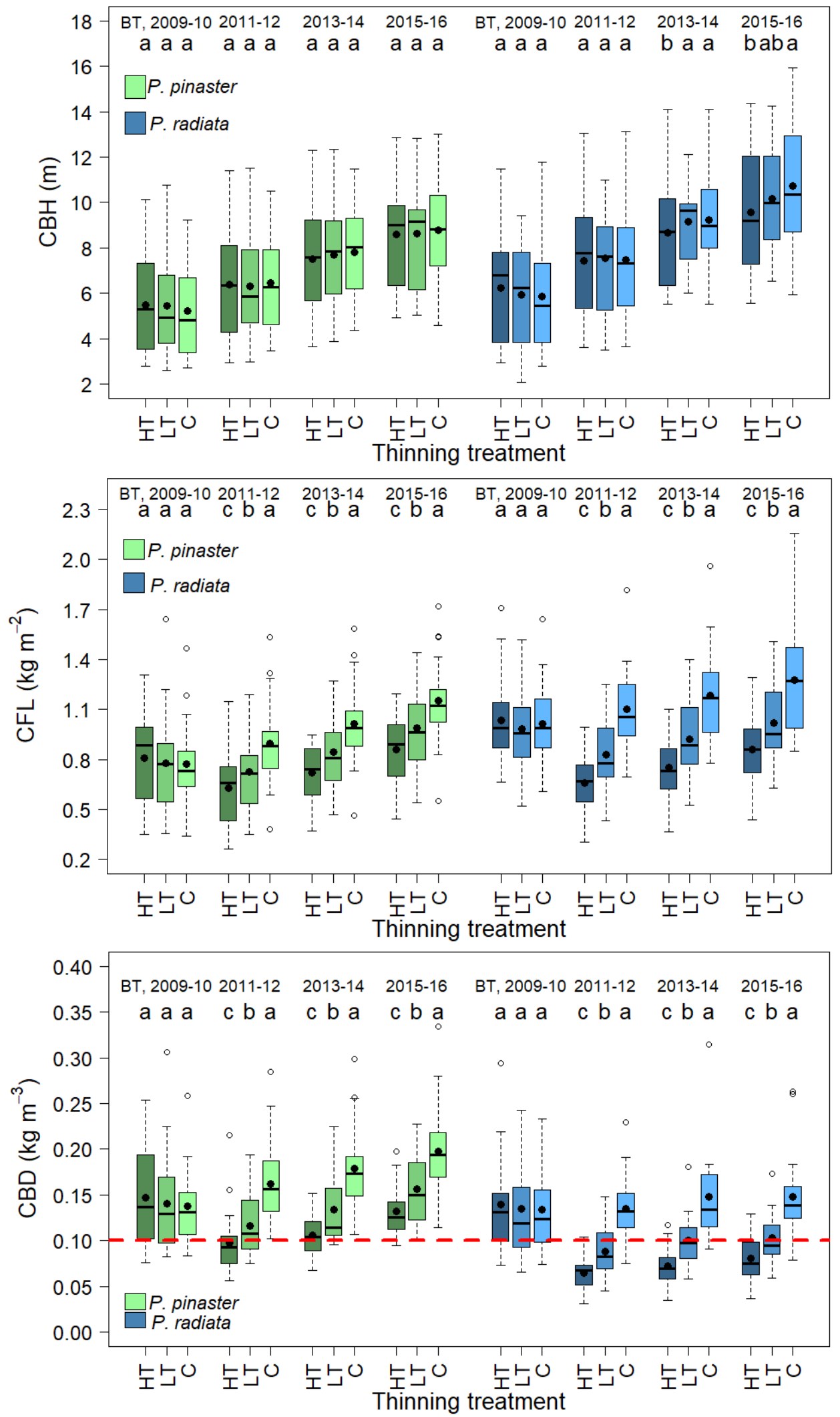

Figure 1 - Box-plots of the canopy variables for each species, inventory and thinning intensity: Control (C), Low thinning $(L W)$ and Heavy thinning $(H T)$. Different letters indicate significant differences between mean values (Tukey's HSD test. $\alpha=5 \%$ ). Black points correspond to mean values.

Significant differences between thinning intensities were found for $C F L$ and $C B D$ for both species in the first post-thinning remeasurement (2011-12). Moreover, the differences were maintained along 
the 6-year period analyzed with a similar pattern for both species. The observed $C B D$ values in the thinning plots at the end of the study period (2015-16) reached the values before thinning for maritime pine but not for radiata pine. The response of $P$. pinaster $C B D$ and $C F L$ agreed with previous results (Jiménez et al., 2016) in a 5 years study, but contradicts the results of Soler et al. (2017) who did not find change in $C D B$ seven years after thinning. It must be noted that the latter study was carried out in older stands and under Mediterranean climate with less precipitation. Fuel management to reduce $C B D$ below the empirical threshold value of $0.10 \mathrm{~kg} / \mathrm{m}^{3}$ has been recommended since the likelihood of active crown fire is strongly reduced (e.g. Scott and Reinhardt, 2001). Six year after treatments only the mean value of the radiata pine trials with heavy thinning remains below this threshold (Figure 1, red dotted line for $C B D$ ).

On the other hand, $C B H$ did not show any change following thinning in $P$. pinaster, a species with marked self-pruning. Jiménez et al. (2016) found significantly higher $C B H$ values in treated plots, probably due to its high pre-treatment stocking. For $P$. radiata, heavy thinning resulted in significantly lower $\mathrm{CBH}$ values since four years after the treatment, likely caused by enhanced lower branch elongation linked to increased light availability.

Since $C B H$ strongly influences the likelihood of crown fire initiation, and $C B D$ the crown fire rate of spread, the results highlight that thinning treatments: (i) may only have a limited impact towards limiting crown fire occurrence, especially in maritime pine stands; and (ii) can have substantial impact in the crown fire rate of spread and in discriminating the type of crown fire, especially in radiata pine stands.

\section{References}

Diéguez-Aranda U, Rojo Alboreca A, Castedo-Dorado F, Álvarez González JG, Barrio-Anta M, Crecente-Campo F, et al. (2009). Herramientas selvícolas para la gestión forestal sostenible en Galicia. Xunta de Galicia. Santiago de Compostela, España.

Hevia H, Crabiffosse A, Álvarez-González JG, Ruiz-González AD, Majada J (2018). Assessing the effect of pruning and thinning on crown fire hazard in young Atlantic maritime pine forests. J. Environ. Manage. 205, 9-17.

Jiménez E, Vega-Nieva D, Rey E, Fernandez C, Vega JA (2016) Midterm fuel structure recovery and potential fire behaviour in a Pinus pinaster Ait. forest in northern central Spain after thinning and mastication. Eur J For Res 135: 675-686

Ruiz-González AD, Castedo-Dorado F, Vega JA, Jiménez E, Fernández-Alonso JM, ÁlvarezGonzález, JG (2015). Modelling canopy fuel dynamics of maritime pine stands in north-west Spain. Int. J. Wildland Fire 24, 92 -102.

Scott JH, Reinhardt ED (2001). Assessing crown fire potential by linking models of surface and crown fire behaviour. USDA Forest Service Res Pap RMRS-RP-29.

Soler Martin M Bonet JA, De Aragón JM, Voltas J, Coll L, Resco V (2017) Crown bulk density and fuel moisture dynamics in Pinus pinaster stands are neither modified by thinning nor captured by the Forest Fire Weather Index. Ann. For. Sci. 74: 51

Van Wagner CE (1977). Conditions for the start and spread of a crown fire. Can. J. For. Res. 7, 23-24. 